\title{
Novoszáth Péter
}

\section{Karcsúsított kormányzás és rezsicsökkentés}

\section{Lean Governance and Utility Price-Cutting Policy}

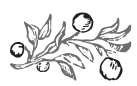

\section{Összefoglalás}

Magyarország nemzetközi összehasonlításban is kirívóan kiszolgáltatottá vált az elmúlt évtizedekben a nagy multinacionális, transznacionális vállalkozásokkal szemben. A külföldi vállalkozások által realizált profit is nálunk volt az egyik legmagasabb. Mindezek jelentôsen felerôsítették a globalizáció, illetve a pénzügyi és gazdasági válság számos negatív következményét. A pénzügyi és gazdasági válság, illetve a válság kezelésének a tapasztalatai megerôsítették azt a paradigmát, hogy a közjó absztrakt normarendszerének érvényesítése érdekében az államnak kell egyre inkább értékteremtô és értékvédô szerepet vállalnia a politikai, gazdasági és társadalmi szférában. A magyar kormány ennek szellemében hosszú távú változásokat kíván végrehajtani, amelyek célja, hogy a szennyvíz-, ivóvíz-, gáz-, áramszolgáltatás, a távfútés, a hulladékkezelés és a közétkeztetés területén a közszolgáltatásokat nonprofit jelleggel biztosítsa az állam annak érdekében, hogy ne a közszolgáltatók profitja, hanem a lakosságnál maradó jövedelem növekedjen. Az Európai Unió ezzel szemben olyan szabályt kíván bevezetni, amely megtiltaná a tagországoknak, hogy maguk határozzák meg a különféle közmúszolgáltatások árát. Be akarják tiltani a rezsicsökkentést.

Journal of Economic Literature (JEL) kódok: D10, D12, D18, D23, D43, E64, H3, L5, Kulcsszavak: fogyasztási közgazdaságtan, fogyasztóvédelem, szervezeti magatartás, jövedelempolitika, árpolitika, szabályozások

Dr. Novoszáth Péter, a közgazdaság-tudomány kandidátusa, egyetemi docens, Nemzeti Közszolgálati Egyetem, ÁKK Közpénzügyi Kutatóintézet (Novoszath.Peter@uni-nke.hu). 


\section{Summary}

Over the past few decades, Hungary has become flagrantly vulnerable even in an international comparison to large multinational and transnational companies. The profit realized in Hungary by foreign companies was also among the highest. All these greatly augmented the numerous negative consequences of globalization and of the financial and economic crisis. The experiences gained of crisis management reinforced the paradigm that in order to enforce the abstract normative system of the common good, the state must increasingly undertake a value-creating and value-protecting role in the political, economic and social spheres. In this spirit, the Hungarian Government intends to implement long-term changes aimed at providing the public with non-profit services in the field of waste water management, drinking water, gas and electricity supply, district heating, waste management and public catering in order to increase the income remaining with the general public rather than the profits of public service providers. The European Union, in contrast, wants to introduce a regulation that would prohibit the Member States to set the prices of the various utility services. They want to prohibit utility cost cut.

Journal of Economic Literature (JEL) codes: D10, D12, D18, D23, D43, E64, H3, L5, Keywords: consumer economics, consumer protection, organizational behaviour, income policy, price policy, regulation

\section{BEVEZETÉS}

Ma már közismert tény, hogy Magyarország sokkal elóbb jutott válságos helyzetbe, mint ahogy maga a világgazdaság válságba került volna. Nálunk komoly lassulás és más jelek is mutattak arra, hogy komoly bajok vannak a globalizáció folyamatához való alkalmazkodásunkban, melyre a külsố környezet negatív változásai ráerôsítettek. Fontos ismernünk, milyen külsố kényszerítô körülményeket diktál egy ország számára, így hazánk számára is a gazdasági globalizáció folyamata, melyhez tudnunk kell alkalmazkodni. Ez nyilvánvalóan nem jelenthet behódolást, inkább olyan pozitív alkalmazkodásra van szükség, ahol a lokalitás érdekei is érvényesülni tudnak. Hasonló kihívásokkal áll szemben a világ számos országa. El kell fogadnunk a tényt, hogy nem tudjuk megváltoztatni a világot a maga teljességében, a magunk környezetét azonban jelentôs mértékben alakíthatjuk. Számos negatív folyamat következményeit orvosolni tudjuk, és képesek vagyunk olyan módon alkalmazkodni, hogy a folyamatokban benne rejlő lehetôségek az elônyünkre váljanak.

Ilyen meghatározó trend az állampolgárok és az üzleti vállalkozások elvárásainak növekedése, a gazdasági integráció negatív hatásaival kapcsolatos kormányzati szerepvállalásra vonatkozóan (Feser, 2007). Döntô részben a globalizáció bôvülése és elmélyülése, valamint a következményeként kitört pénzügyi és gazdasági válság negatív következményei és az azokra nem reagáló, illetve téves válaszokat adó, éppen a negatív 
hatásokat felerôsítő kormányzati politika vezetett odáig 2002 és 2010 között Magyarországon, hogy a választópolgárok kétharmados egységben döntöttek arról, nálunk is a globális folyamatokat is befolyásolni képes állami aktivitás erôsítése és a negatív hatásokkal szemben jóval erósebb kormányzati fellépés szükséges.

Az elmúlt évtizedekben Magyarország nemzetközi összehasonlításban is kirívóan kiszolgáltatottá vált a multinacionális, transznacionális vállalkozásokkal szemben. Mindezt leginkább az támasztja alá, hogy 2008-ban, a válság kitörésekor a pénzügyi mérleg nálunk mutatta a legnagyobb többletet, vagyis a tôkekiáramlás mértéke (pénzszivattyú) nemzetközi összehasonlításban Magyarország esetében volt a legnagyobb Izland után, megelôzve Görögországot.

Ezen túlmenôen a külföldi vállalkozások által realizált profit is nálunk volt az egyik legmagasabb (OECD, 2010:179, 231, Figure J.4.1), és az importpenetráció mértéke is kimagasló volt (OECD, 2010:77, Figure C.10.2), valamint a pénzügyi szektorban a külföldi vállalatok befolyása szintén kiugróan magas volt nemzetközi összehasonlításban (OECD, 2010:165, Figure I.5.3). A technológiai mérlegünk (OECD, 2010:129, Figure F.7.4) erôsen negatívvá vált, és a kutatás-fejlesztési tevékenységek múködtetésében is a multinacionális vállalatok meghatározó súlya vált jellemzôvé. Az élelmiszerek, italok és dohánytermékek forgalmazása és a nagy- és kiskereskedelem terén a külföldi vállalkozások kiemelkedô részesedést értek el Magyarországon (OECD, 2010:163, Figure I.4.1). A hazai eredetú hozzáadott érték alacsony maradt nemzetközi összehasonlításban (OECD, 2010:209, Figure L.1.1) Mindezek jelentôsen felerôsítették a globalizáció és a pénzügyi és gazdasági válság számos negatív következményét, többek között ezért is volt Magyarországon a legnagyobb a gazdasági visszaesés a válság kitörésekor, és került a gazdaság minden területen összeomlásközeli állapotba.

A pénzügyi és gazdasági válság, illetve kezelésének a tapasztalatai megerôsítették azt a paradigmát, hogy a közjó absztrakt normarendszerének érvényesítése érdekében az államnak kell egyre inkább értékteremtô és értékvédố szerepet vállalnia a politikai, gazdasági és társadalmi szférában. Ez nem jelenti a társadalomtól való elkülönülést, éppen ellenkezóleg: az állam autonómiája széles körú társadalmi beágyazottság, a társadalom különféle szereplőivel, szervezett érdekcsoportjaival történó párbeszéd - többek között ezt szolgálja a Nemzeti Konzultáció -, valamint az ebból nyert felhatalmazás alapján és birtokában szolgálja a gazdasági-társadalmi fejlődést.

\section{A Nemzeti Konzultáció, mint a Közösségi értékeK MEGJELENÍTÉSÉNEK ÚJ ESZKÖZE}

A döntéshozóknak mindig tisztázniuk kell, hogy az általuk meghozandó döntések, intézkedések, sốt meg nem hozott intézkedéseik milyen hatással lesznek nemcsak az érintett társadalom, közösség egészére, hanem gyakorlatilag minden egyes állampolgárra. Olyan döntési rendszert kell múködtetniük, amely a különféle gazdasági vagy más szakmai szempontok racionalitásának vizsgálatán felül az érintett emberek sorsára is tekintettel van, ezért a döntések nem válnak személytelenné (Novoszáth, 2011:341-357). 
A közösségi értékek koncepciója, szemben a korábban elterjedt új közszolgálatimenedzsment-irányzatokkal, lehetőséget nyújt arra, hogy jól használható módon gondolkodjunk a közpolitika céljairól és teljesítményérôl. Egyúttal mérhetôvé teszi mindazoknak a tevékenységeknek a teljesítményét, eredményességét, amelyeket az állam maga végez vagy finanszíroz a köz szolgálatában (beleértve azokat a szolgáltatásokat is, amelyeket az állam finanszíroz, de valójában más szervezetek, például magánvállalatok vagy nonprofit szervezetek végeznek). A közösségi értékek lényegesen szélesebb horizontú értékmérôk, mint amelyet valaha a közszolgálatimenedzsment-teóriák eddig használtak, beleértve a legújabb közszolgálatimenedzsment-koncepciókban megfogalmazottakat is, mivel a teljesítmények értékelése mellett a bizalom és a legitimáció változását is értékeli (Mulgan, 2008). Ráadásul olyan kérdéseket is megvizsgál, mint a méltányosság, az erkölcsiség és az átláthatóság. A jelenleg nálunk is elterjedt és alkalmazott új közszolgálatimenedzsment-teóriák a legtöbb esetben nem térnek ki, vagy nem súlyuknak megfelelóen értékelik e tényezóket és a gazdasági, társadalmi következményeket (Cole-Parston, 2006:188). Ha csupán hagyományos pénzügyi mutatókra támaszkodva akarjuk megítélni a közigazgatás, a közszolgáltatások egészének vagy egy-egy szeletének, projektjének sikerét, hibát követhetünk el: olyan területeket fogunk támogatni, amelyek nem termelnek valódi értéket, és nem biztosítunk forrásokat olyan területek számára, amelyek értékteremtôk lehetnének (Moore, 1995:402).

Korábban az új közszolgálatimenedzsment-teóriák a közérdek azonosítására az egyéni preferenciák aggregálását, összegzését alkalmazták közösségi igényként bemutatva. Sokan emlékszünk még a jóléti rendszerváltás blöffjére, amelyet ilyen módon építettek föl. Ez a módszer azonban sokszor jelentősen torzítva, manipulálva adta viszsza a társadalom valós értékítéletét, ezért sokkal kifinomultabb módszerre volt szükség, amely az egyéni és közösségi preferenciákat közösségi mérlegelés és szavazás eredményeként azonosítja. Ez a „közösségi érték” megközelítés sajátja, amelyet számos országban is alkalmaznak. ${ }^{1}$ A Nemzeti Konzultáció egyértelmú célja, hogy az ország számára legfontosabb, tervezett intézkedéseket a választópolgárokkal, a társadalommal folytatott közvetlen párbeszéd segítségével hozzák létre. A kezdetben a Miniszterelnökség, késôbb a Miniszterelnöki Kabinetiroda által koordinált nemzeti konzultációs kérdőívek kiértékelését a Közigazgatási és Elektronikus Közszolgáltatások Központi Hivatala (KEK KH) végzi.

Az Alaptörvényrôl készült kérdőívre 2011 februárjában mintegy 920 ezer válasz érkezett. A 2011 májusában kiküldött, idôsekkel, devizahitelesekkel, közmúszolgáltatókkal, oktatási támogatásokkal kapcsolatos kérdéseket tartalmazó kérdőívet már több mint egymillióan küldték vissza. A 2012 szeptemberében kiküldött „gazdasági kérdőív” adózással, járulékokkal, a nagyvállalatokkal és közmúcégekkel, a minimálbérrel és a nyugdíjakkal, valamint a devizahitelesekkel kapcsolatos kérdéseket tartalmazott, és mintegy 700 ezren válaszoltak. A terrorizmussal, menekültekkel, bevándorlókkal, az Európai Unióval kapcsolatos kérdéseket tartalmazó kérdőívet 2015 májusában közel egymillióan töltötték ki.

A 2017 áprilisában szétküldött „Állítsuk meg Brüsszelt” címú konzultációs kérdôív részvételi rekordot döntött, miután 1 millió 680 ezren küldték vissza (Magyar Idôk, 
2017). A Nemzeti Konzultáció egyértelmú célja ebben az esetben az volt, hogy a magyar kormány megismerje, a magyar emberek közül milyen sokan és mennyiben támogatják a kormánynak a brüsszeli döntéshozóktól eltérô álláspontját a rezsicsökkentés és a migránsok beengedése vonatkozásában. A magyar érdekeket a magyarok ismerik a legjobban, ezért volt Magyarország szempontjából döntô, hogy minél többen vegyenek részt a kormány által kezdeményezett Nemzeti Konzultációban.

\section{A KARGSÚSítoTt KORMÁNYZÁS GÉLJA}

A karcsúsított kormányzás célja, hogy a kormányzás eredményessége és hatékonysága az állampolgárok szolgálatában folyamatosan javuljon, a szolgáltatások nyújtása folyamatában a felesleges és nem hatékony elemeket kiszúrjék és megszüntessék (Miller, 2009), egyúttal egyre jobb és költséghatékonyabb szolgáltatások álljanak az állampolgárok rendelkezésére. Ez korántsem egyszerú feladat a gyakorlatban, hiszen például a kormányablakok számának növelése nyilvánvalóan csökkenteni tudja az ügyintézési időt, a várakozási időket és az egy ügyintézőre jutó ügyfelek számát, és mindez lehetôséget ad a minôség javítására is, mindeközben új kormányablakok létesítése akár jelentősen is megnövelheti a költségeket, ronthatja a költséghatékonyságot. Ilyen módon a karcsúsított kormányzás technikáinak alkalmazása valójában az értékteremtés és értéknövelés egyik fố támogató eszköze a gyakorlatban.

A karcsúsított kormányzási technikákat tehát összességében akkor alkalmazzák helyesen, ha végeredményben a kormány kapacitásai bôvülnek, és egységnyi ráfordítás felhasználásával több szolgáltatást képes nyújtani legalább ugyanolyan vagy a korábbinál jobb minôségi színvonalon. A karcsúsított kormányzás technikái alkalmazásának másik elônye, hogy a folyamatok egymáshoz kapcsolódásának jobb megértéséhez vezetnek, ennek következtében megkönnyítik a fejlesztendő elemek, területek gyorsabb azonosítását, és ennek eredményeként a fejlesztések végrehajtását is hatékonyabbá és gyorsabbá tehetik. Végeredményben pedig segíthetik egy folyamatos fejlesztéseket elôsegítố kultúra létrejöttét (Waits, 2008).

A versenyképességük és a versenypozíciójuk megőrzése érdekében sokszor egyes globális cégek annak tudatában alakítják költségeik színvonalát, hogy tudják, a termékeik, szolgáltatásaik árát nem növelhetik, csak csökkenthetik. Ennek megfelelóen számos, a gyártási folyamatok hatékonyságának és eredményességének javítására alkalmazott módszer (például a VSM, Kaizen, 5S, hat Sigma stb.) a közigazgatásban is sikerrel alkalmazható (Venegas, 2007). Ezt nevezik a szakemberek karcsúsított kormányzásnak. A magyar kormány felismerte, hogy mindezek a módszerek a közmúszolgáltatások esetében is sikerrel alkalmazhatók. A karcsúsított kormányzás szempontjából Magyarországon kiemelkedô jelentôségú az úgynevezett rezsicsökkentés folyamata, amely révén számos közszolgáltatás költségeit sikerült csökkenteni, és markánsan csökkentek a közmútartozások is a rezsicsökkentés hatására.

A minél nagyobb eredmény elérése érdekében a magánkézbe adott közszolgáltatások irányítói a lehetô legkisebb eszköz- és erôforrás-befektetésére törekszenek (pl. az alkalmazottak számának és a fejlesztési kiadásoknak a minimalizálása), és a lehetô 
legmagasabb áron adják szolgáltatásukat, amelyet általában a szolgáltatások díjának növelésével, más esetekben a szolgáltatások terjedelmének, minőségének és az igénybevevốk körének csökkentésével, vagy mindezen módszerek együttes alkalmazásával érnek el. A szolgáltatások igazi értéke az adott közösség számára, az állampolgárok életminôségének javulása ettôl kezdve teljesen érdektelenné válik. Mégis a közszolgáltatások fejlesztésének egyedüli eszközeiként az Európai Unió ma is csupán a privatizáció, a piacosítás, az energiaunió lehetôségét támogatja. Ezért volt itt az ideje, hogy nemzetközi téren és itthon is egyébként jól ismert és sok helyen sikerrel alkalmazott más típusú megoldások, így mindenekelôtt a nonprofit szolgáltatások, az árak és a minôség a korábbiaknál sokkal szigorúbb szabályozása kapjon teret és lehetôséget annak érdekében, hogy ne a közszolgáltatók profitja, hanem a lakosságnál maradó jövedelem növekedjen. A magyar kormány ennek szellemében hosszú távú változásokat kíván végrehajtani, amelyek célja, hogy a szennyvíz-, ivóvíz-, gáz-, áramszolgáltatás, a távfútés, hulladékkezelés és a közétkeztetés területén a közszolgáltatásokat nonprofit jelleggel biztosítsa az állam.

\section{A REZSiCSÖKKENTÉs CÉlJa és ÉRTELME}

A magyar lakosság körében a háztartások bevételeik 81\%-át mindennapi kiadásokra, ezen belül is a legtöbb pénzt, kiadásaik 32\%-át rezsiköltségekre, 31\%-át élelmiszerekre kell kifizetniük. A közgazdaság-tudomány egyik legrégibb tétele, az Engel-törvény szerint a háztartások esetében a magasabb életszínvonalhoz alacsonyabb élelmiszer-kiadási arány tartozik. Ezért különösen az átlag alatti jövedelemmel rendelkezô lakosság számára fontos az alapvetó élelmiszerek áfájának csökkentése. Amely amellett, hogy több tízezer forintos megtakarítást jelent évente, egyúttal a megélhetés biztonságát garantálja a lakosság egy jelentôs része számára.

A háztartások fogyasztási szerkezetének vizsgálatából azt is megtudhatjuk, hogy míg a 2005-ös adatfelvétel idején a kiadások egynegyedét tették ki a lakásfenntartással kapcsolatos költések, addig 2012-re már a kiadások egyharmadát jelentette ez a tétel. A háztartások kiadásai közül a lakásfenntartással kapcsolatos kiadások drasztikusan növekedtek a 2012 előtti, nyolcéves időszakban. A 2010 elôtti kormányok idején egyes közmúszolgáltatóknak nyolc év alatt tizenötször is lehetôségük volt áremelésre. Ennek eredményeként 2000 után az összes, a lakosság által használt energiafajta ára jobban nôtt, mint az átlagos árszínvonal. Leginkább a vezetékes gáz ára növekedett.

2007-ben Magyarországon akkor is kiugróan emelkedett a gáz ára, amikor a világon egyébként csökkent. Ennek eredményeként 2010-re Európában már hazánkban volt az egyik legmagasabb a gáz ára. Ezért kezdett bele a 2010-ben megalakult új kormány a rezsicsökkentési programjába. E program fô célkitúzése az lett, hogy a közmúvek terén a családok számára megfizethetố ár alakuljon, és Európában a magyar családok juthassanak a legolcsóbban energiához. Minimális profitot természetesen kell biztosítani a közmúvállalkozóknak is, hogy kelló fedezetük legyen a szolgáltatások minôségének javítására és az ellátás biztonságának fenntartására, de nem minden korlát nélkül. 
Magyarországon a rezsicsökkentés elsô üteme 2013. január elsejével indult. Ekkor 10 százalékkal csökkent a gáz, az áram és a távhố díja, és ezt az intézkedést további javaslatok, intézkedések követték a háztartási PB-gáz-palackok, a hulladékszállítás, a víz- és csatornadíjak, valamint a kéményseprés vonatkozásában. A rezsicsökkentést a parlament április 29-én törvényben rögzítette (1. táblázat). ${ }^{2}$

\section{1. táblázat: A rezsicsökkentés lépései}

\begin{tabular}{|c|c|c|c|c|c|c|c|c|}
\hline \multicolumn{9}{|c|}{ Rezsicsökkentés (1., 2. és 3. ütem) } \\
\hline & \multicolumn{4}{|c|}{2013} & \multicolumn{4}{|c|}{2014} \\
\hline & jan. 1. & júl. 1. & nov. 1. & összesen & ápr. 1. & szept. 1. & okt. 1. & összesen \\
\hline Földgáz & $-10 \%$ & & $-11,1 \%$ & $-20 \%$ & $-6,5 \%$ & & & $-25,19 \%$ \\
\hline Villany & $-10 \%$ & & $-11,1 \%$ & $-20 \%$ & & $-5,7 \%$ & & $-24,55 \%$ \\
\hline Távhó & $-10 \%$ & & $-11,1 \%$ & $-20 \%$ & & & $-3,3 \%$ & $-22,63 \%$ \\
\hline $\begin{array}{l}\text { Víz + } \\
\text { csatorna }\end{array}$ & & $-10 \%$ & & $-10 \%$ & & & & $-10 \%$ \\
\hline PB-gáz & & $-10 \%$ & & $-10 \%$ & & & & $-10 \%$ \\
\hline Hulladék & & $-10 \%$ & & $-10 \%$ & & & & $-10 \%$ \\
\hline \multirow[t]{2}{*}{$\begin{array}{l}\text { Kémény- } \\
\text { seprés }\end{array}$} & & $-10 \%$ & & $-10 \%$ & & & & $-10 \%$ \\
\hline & \multicolumn{2}{|c|}{ 1. ütem } & 2. ütem & & \multicolumn{3}{|c|}{ 3. ütem } & \\
\hline
\end{tabular}

Forrás: Horváth, 2016:3

A Magyarországon végrehajtott rezsicsökkentő intézkedések eredményeként 2013-ban és 2014-ben három lépésben, összesen 25,19\%-kal mérséklődött a földgáz, 24,55\%-kal a villamos energia, 22,63\%-kal a távhő ára. A víz- és csatornaszolgáltatás, a PB-gáz, a hulladékszolgáltatás és a kéményseprés díjai 10\%-kal mérséklődtek.

Az Eurostat kimutatásai szerint az európai országok sorrendjében a földgázárak vonatkozásában hazánk 2010 elsố felében még a 17. helyen állt, 2016-ban azonban már nálunk volt a második legolcsóbb a földgáz ára (1. ábra). Az ábrán jól látható, hogy 2010-ról 2016-ra Dánia után Magyarországon volt a legnagyobb a gázárak csökkenése.

A villamos energia lakossági árai tekintetében az európai országok sorrendjében hazánk 2010 elsô felében még a 16. helyen állt, de 2016-ban már a 3. legolcsóbb volt. Nálunk a lakosság 2013. január 1-je és 2015. december 31-e között összesen 642 milliárd forintot takaríthatott meg a rezsicsökkentés hatására. A legtöbbet, 278 milliárd forintot a villanyszámlán spóroltak a fogyasztók, a földgáz esetében 240 milliárd forint volt a lakossági felhasználók összes megtakarítása. Jelenleg éves szinten a lakosság megtakarítása 268 milliárd forint. A Magyar Energetikai és Közmúszabályozási Hivatal adatai alapján egy nyugdíjas házaspár éves megtakarítása 83-116 ezer forint között alakul, míg egy kétgyermekes családé éves szinten 109-112 ezer forint között mozog.

Hazánkban a legtöbbeket érintô lakhatási probléma a rezsi-, lakbér- és lakáshitelelmaradás. Egy európai felmérés szerint a lakosság 26\%-a, vagyis 2,6 millió ember háztartásának van befizetési hátraléka. Ez az esetek jóval nagyobb arányában takar 
közmútartozást (2,3 millió fô), mint lakbér- vagy lakáshitel-elmaradást (680 ezer fô). A szegénységi küszöb alatt élốk 63\%-ának volt valamilyen típusú tartozása, amellyel az EU-ban a legrosszabb helyezést értük el 2013-ban (Koltai, 2014:6).

A rezsiköltségek csökkentése a korábban felhalmozott hátralékok alakulására is kedvezố hatással volt. 2012-rôl 2016-ra 48\%-kal esett vissza a földgáz-, villany- és távhốszámla-tartozások összege (2. ábra).

Egyúttal mind a késedelembe esett háztartások, mind pedig a kikapcsolt felhasználók száma is jelentôsen csökkent az elmúlt években. 2012-ról 2016-ra 45\%-kal kevesebb lett a késedelembe esett háztartás, és 31\%-kal lett kevesebb a kikapcsolt felhasználó (3. ábra).

\section{ÁrAK BEFAGYASZTÁSA VERSUS ÁRSAPKA-SZABÁLYOZÁS}

Nem ez az elsố eset, hogy külföldi országok átvesznek olyan kezdeményezéseket, amelyeket az Orbán-kormány valósított meg elsóként Európában. Az energia- és közmúszolgáltatási szektor teljes privatizációja és az ennek nyomán meredeken emelkedô energiaár nem egyedülálló jelenség Európában, de a kontinens erôs országai szigorú szabályokkal mindeddig, úgy túnt, kordában tudták tartani ezeket a szolgáltatókat. Mégis a lakosság jelentôs részének szimpátiájától kísérve, a magyarországi mintát követve, az energiaárak lefaragásával kampányolt a brit Munkáspárt a 2015-ös egyesült

\section{1. ábra: Földgázárak változása a rezsicsökkentés elōtt és után}

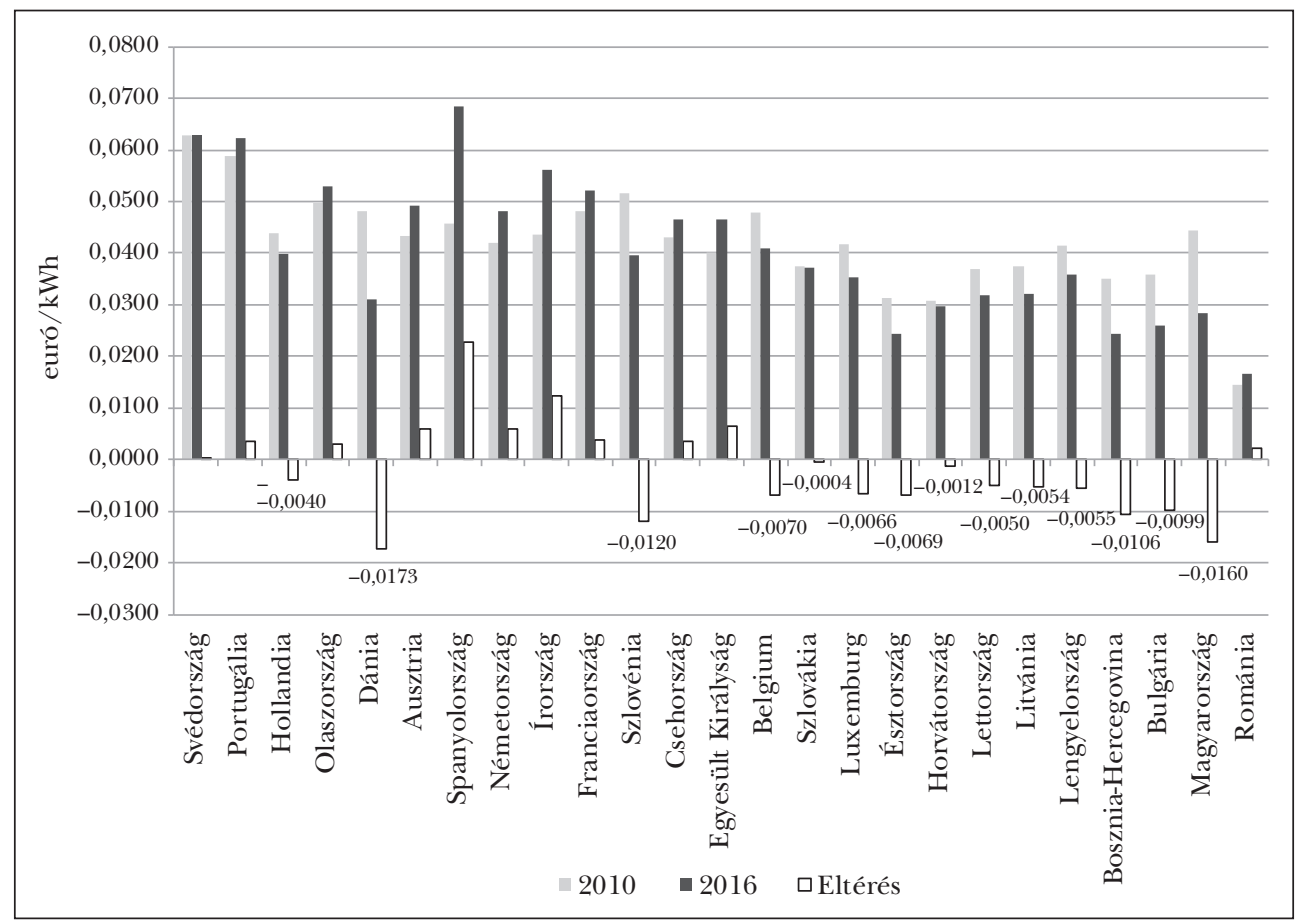

Forrás: Eurostat, 2007a 
2. ábra: A díjhátralékok alakulása 2012 és 2016 között

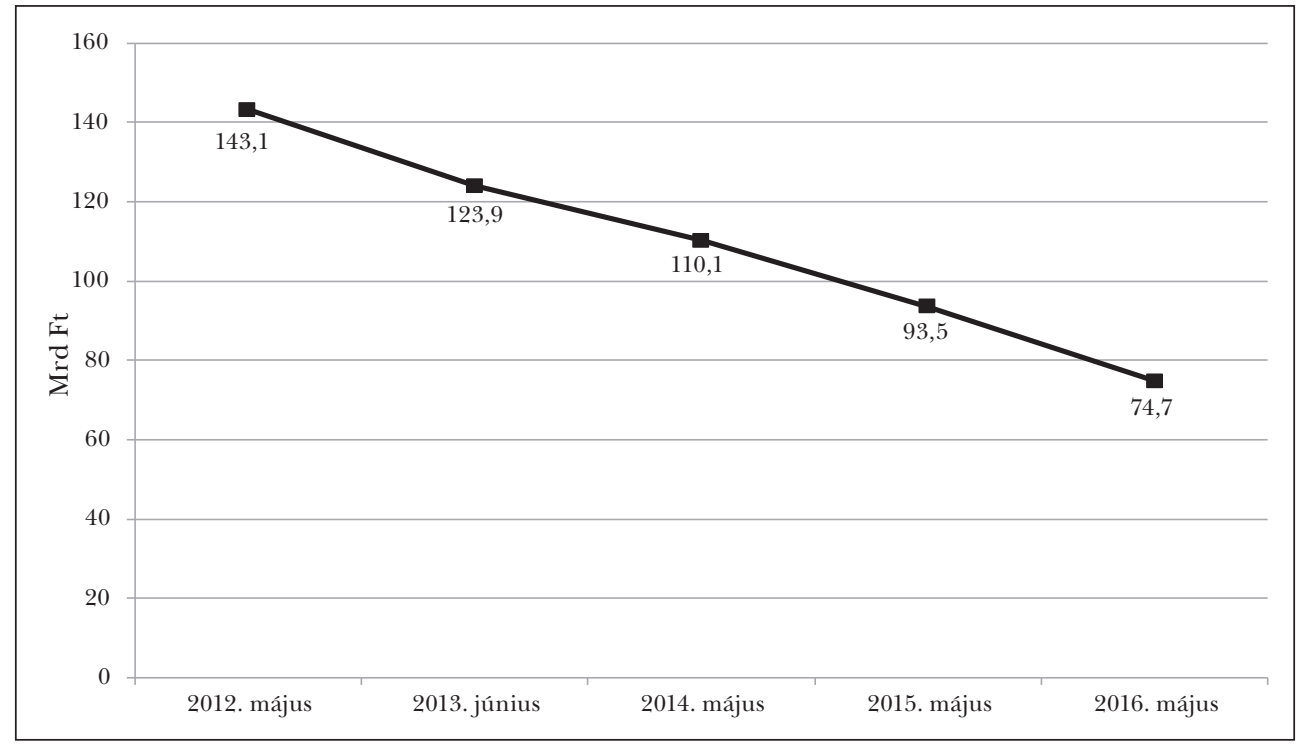

Forrás: Saját szerkesztés Horváth, 2016:8 alapján

3. ábra: A késedelembe esett és a kikapcsolt lakossági felhasználók számának alakulása 2012 és 2016 között

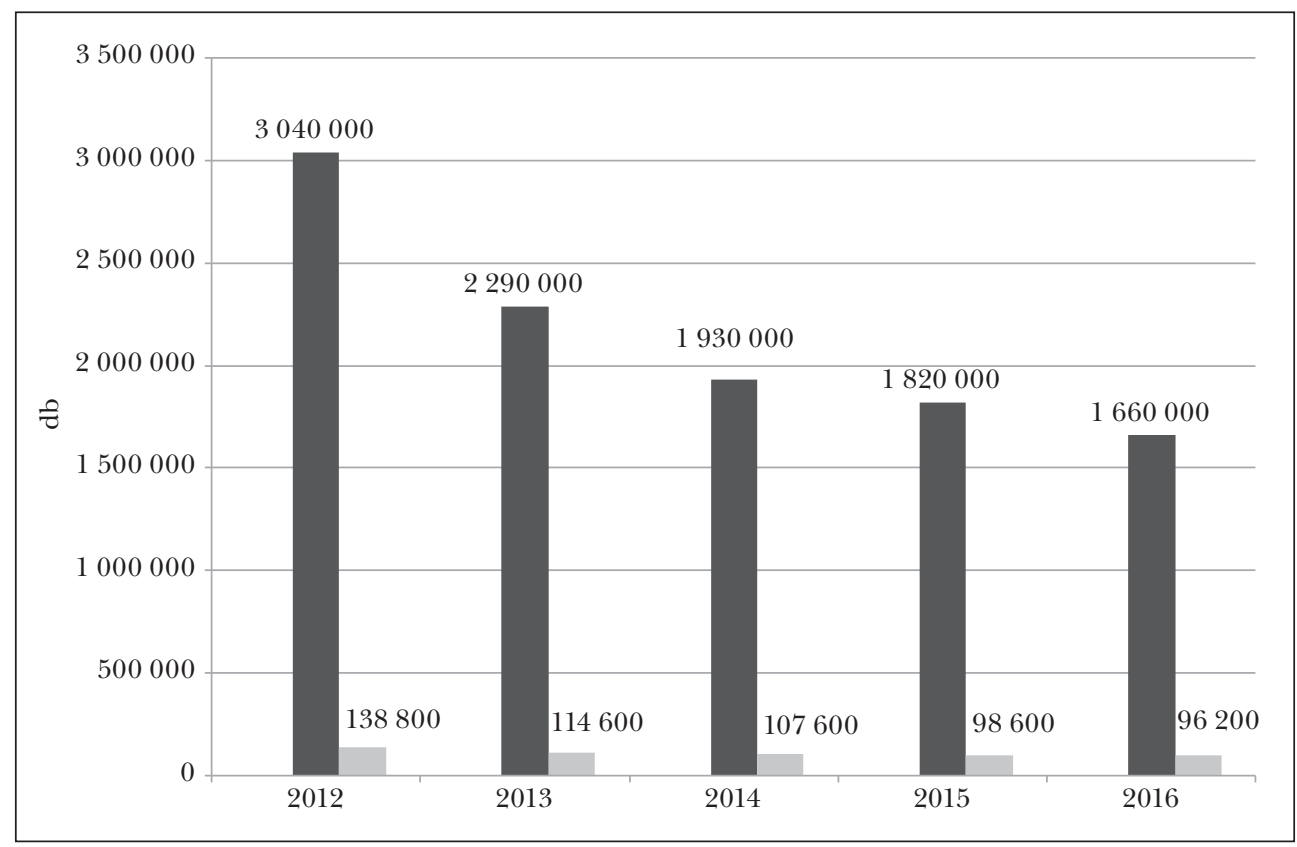

Forrás: Saját szerkesztés Horváth, 2016:9 alapján 
királysági választások során. A brit Munkáspárt vezére a 2015-ös brit választások alkalmával megígérte a választóinak, hogy húsz hónapra befagyasztaná a lakosság és a családi vállalkozások rezsiköltségeit, ha pártja kormányra kerülne. Ed Miliband szerint az energiacégek túl hosszú ideje számláznak az indokoltnál többet, és ezt azért tehetik meg, mert nincs megfelelố verseny a piacon. A politikus levélben sürgette az energiaszolgáltatókat, hogy segítsék valóra váltani terveit (Baker, 2015). Az energiaszolgáltató cégek azonban dühösen reagáltak az elképzelésre: szerintük egy ilyen döntés következtében akár áramkimaradások is bekövetkezhetnek.

A brit fogyasztói érdekvédelmi szervezetek szerint azonban Nagy-Britanniában egyre több kisnyugdíjas és alacsony jövedelmú család képtelen kifizetni a közmúszámláit. A CMA 2016-os jelentésében megállapította, hogy az Egyesült Királyságban kikapcsolt belföldi energiafogyasztók 90 százaléka képtelen vagy nem hajlandó energiaszolgáltatót váltani (CMA, 2016). Vagyis a piaci mechanizmusok korántsem múködnek megfelelően, és nem biztosítják a piaci helyzetükkel visszaéló szolgáltatók feletti megfelelố ellenôrzést, a lakosság érdekeinek magas szintú érvényesíthetôségét. Ezért nem véletlen, hogy a 2017. évi júniusi választásokon már nemcsak a Munkáspárt ígérte meg a brit választóknak, hogy megválasztásuk esetén megakadályozzák a háztartások energiakiadásainak növekedését, hanem a konzervatívok is. A konzervatív párt megígérte, ha nyer a júniusi választásokon, beavatkozik a gáz- és a villamosenergia-árak alakításába, és a brit háztartások kétharmadánál korlátozni fogja az árak emelésének lehetőségét. Mindazonáltal a jobboldali konzervatívok politikája némiképpen eltért a Munkáspártétól, mivel ók nem az árak befagyasztását, hanem egy új ársapka (price cap) jellegú szabályozás bevezetését ígérték meg a választóiknak. Véleményük szerint az ó elgondolásuk sokkal rugalmasabban lesz képes reagálni a piaci viszonyok változásaira. Egyes elemzôk szerint ez a megoldás az egyik legnagyobb energiaszolgáltató cég esetében 332 millió fonttal csökkentené a cég profitját, és mintegy 4,2 millió fonttal a vezérigazgató éves jövedelmét. A Centrica 2016-ban rekordösszegú, 2,2 milliárd fontos adózás elootti profitra tett szert (Pickard-Thomas, 2017).

Egy másik érdekes fejlemény ebben az ügyben, hogy a nagy brit energiaszolgáltató cég, a Scottish and Southern Energy (SSE) a kirobbant vita kapcsán, 2016 novemberében vállalta, hogy legalább hat hónapig befagyasztja a standard gáz- és villamosenergiaárait, egészen 2017 áprilisáig, ezzel mintegy 100 font megtakarítást lehetôvé téve, és az egyik legalacsonyabb árat ajánlva a piacon a fogyasztóknak. A 8 millió fogyasztóval rendelkezô SSE bejelentése meglepetésként érte a többi energiaszolgáltatót, hiszen a tél előtt sokkal inkább az árak további emelését várták. Ugyanakkor az SSE kezdeményezése a mai napig nem talált követôkre, a legtöbben nem is reagáltak a hírre, míg többen, mint a British Gas és Npower, valamint a francia EDF a szóvivőjén keresztül csak annyit üzent, hogy cégük folyamatosan felülvizsgálja az árakat. Az újságírók szellemesen azzal zárták beszámolójukat, hogy amennyiben bármilyen új fejleményrôl érkezne hír a témában, haladéktalanul tájékoztatják a nyilvánosságot, de 2016 novembere óta egyetlen új bejelentés sem érkezett más energiaszolgáltatóktól (Borrell, 2016).

Csehországban is megvalósult egy tízszázalékos mérséklés, s Bulgáriában és Németországban is sor került kisebb mértékú árcsökkentésekre (Magyar Nemzet, 2013). De 
mindezek ellenére, Magyarországon kívül továbbra is a gáz- és villamosenergia-árak emelkedô trendje maradt a jellemzô az Európai Unióban.

\section{Az Európai BizotTság A PIAC MindenhatóságábAN Hisz}

A Századvég kutatóintézet 2013. április 26. és 30. között telefonos, kérdőíves közvélemény-kutatást végzett, amelynek során 1000 véletlenszerúen kiválasztott személyt kérdeztek meg. ${ }^{3}$ E felmérés tanúsága szerint a magyar lakosság jelentôs többsége találkozott a kormány rezsicsökkentô intézkedéseit ért kritikákkal, túlnyomó többségük (59\%) nem érzi jogosnak ezeket a bírálatokat. E felmérés alapján az is elmondható, hogy a lakosság túlnyomó többsége (82 százaléka) az elhangzott kritikák után is ugyanannyira vagy jobban támogatja a rezsicsökkentést, mint korábban. Összességében tehát a Századvég 2013 áprilisában készített közvélemény-kutatása azt támasztotta alá, hogy a lakosság döntô többsége nem érzi jogosnak a rezsicsökkentést ért kritikákat, és az intézkedések lakossági támogatottsága továbbra is magas.

Az Európai Bizottság, az Európai Uniót létrehozó alapítók szellemével ellentétben, egyre több kérdésben akar a nemzetállamok feje fölött dönteni. A brüsszeli bürokraták el akarják venni a lehetôséget a nemzetállamoktól, hogy azok szuverén módon dönthessenek arról, hogy kontrollálják a közmúszolgáltatókat. Ez a kérdéskör azért kapott helyet a konzultációban, mert Energiaunió címmel az Európai Bizottság olyan javaslatot tett le az asztalra, amely kivenné az áramár meghatározásának jogát a tagállamok kezéból (Magyarország Kormánya, 2017). Brüsszel javaslata értelmében a tagállamoknak ütemtervet kellene készíteniük „az összes szabályozott díjtétel feloldására”. Ez gyakorlatilag a rezsicsökkentés végét jelentené, és azt is, hogy a nagyvállalatok újra szabad kezet kapnának a rezsidíjak meghatározásában. Ez az elképzelés a magyar családok helyett újra a multiknak kedvezne, ezért a kormány határozottan ellenzi.

Az Európai Bizottság, úgy tûnik, a tények ellenére csak a piac mindenhatóságában hajlandó hinni, és egyelôre semmilyen egyéb alternatív megoldást nem kíván megfontolni. Az Európai Unió az üzletágban érdekelt magáncégek támogatására 2015 decemberében támadást indított a magyar rezsicsökkentés folyamata ellen, amelynek elókészítése gyanánt több uniós államot is hasonló vizsgálat alá vontak (Somogyi, 2015). Az ítélet gyakorlatilag megszületett: a vizsgálat elindításakor a vizsgált államok erôfölényükkel visszaélve úgy léptek föl, hogy veszélybe sodorták a magán-közszolgáltató cégek fennmaradását. Az EU mindeddig még egyetlen kötelezettségszegési eljárást sem indított olyan magán-energia- vagy közszolgáltató ellen, amely visszaélt az erôfölényével, sôt mi több, megkárosította a fogyasztókat, például túlszámlázás vagy felesleges, pazarló költségeinek áthárítása révén.

Az Európai Bizottság írásos állásfoglalásában kimondja, hogy a piaci liberalizáció alacsonyabb árakat jelent. Ezzel szemben az Európai Bizottság saját korábbi jelentéseiből világosan kiderül, hogy az áram lakossági fogyasztói árai 2010 és 2015 között átlagosan 20 százalékkal növekedtek az uniós országokban (az Egyesült Királyságban 50 százalékkal, Portugáliában 37 százalékkal). A lakossági gázárak esetében még roszszabb a helyzet: öt év alatt átlagosan 25 százalékkal noottek a fogyasztói árak az Európai 
Unióban (Spanyolországban például 72 százalékkal). Eközben Magyarországon csökkentek a legnagyobb mértékben a rezsiköltségek Európában (European Commission, 2014:33).

Az Európai Unió álláspontját képviselô hazai szakértốk szerint, a központilag vezérelt rezsicsökkentés kevésbé sikeres, mint az Unió által erőltetett piaci koordináció. Véleményük szerint Csehországhoz és Szlovéniához képest, amelyek teljes egészében liberalizálták a lakossági piacot, a magyar árak csökkentek legnagyobb mértékben, de nominálisan alig alacsonyabbak, mint azokban az országokban, ahol teljesen liberalizálták az árakat (Felsmann, 2016).

Ezzel szemben az az igazság, hogy az Európai Unióban jelenleg a legmagasabbak az energiaárak a világon, és különösen azokban az országokban, ahol teljes mértékben liberalizálták a piacot. Az utóbbi években éppen ezekben az országokban nôttek a legnagyobb mértékben az árak, például az Egyesült Királyságban több mint 50 százalékkal.

Kaja Kallas észt képviseló szerint nekik már van tapasztalatuk az EU által javasolt rendszerről, amely véleménye szerint náluk a rezsi csökkenését eredményezte (Hír TV, 2017). Kétségtelen, hogy európai összehasonlításban az észt villamosenergia-ár 2016-ban a harmadik legalacsonyabb volt, ugyanakkor 2010-ben még a második legalacsonyabb. Tehát valójában a pozíciójuk nem javult, hanem romlott, ezzel szemben Magyarországé jelentôsen javult. A 4. ábrán jól látható, mely országokban csökkentek az árak, és milyen mértékben.

\section{4. ábra: Villamosenergia-árak a rezsicsökkentés elótt és után}

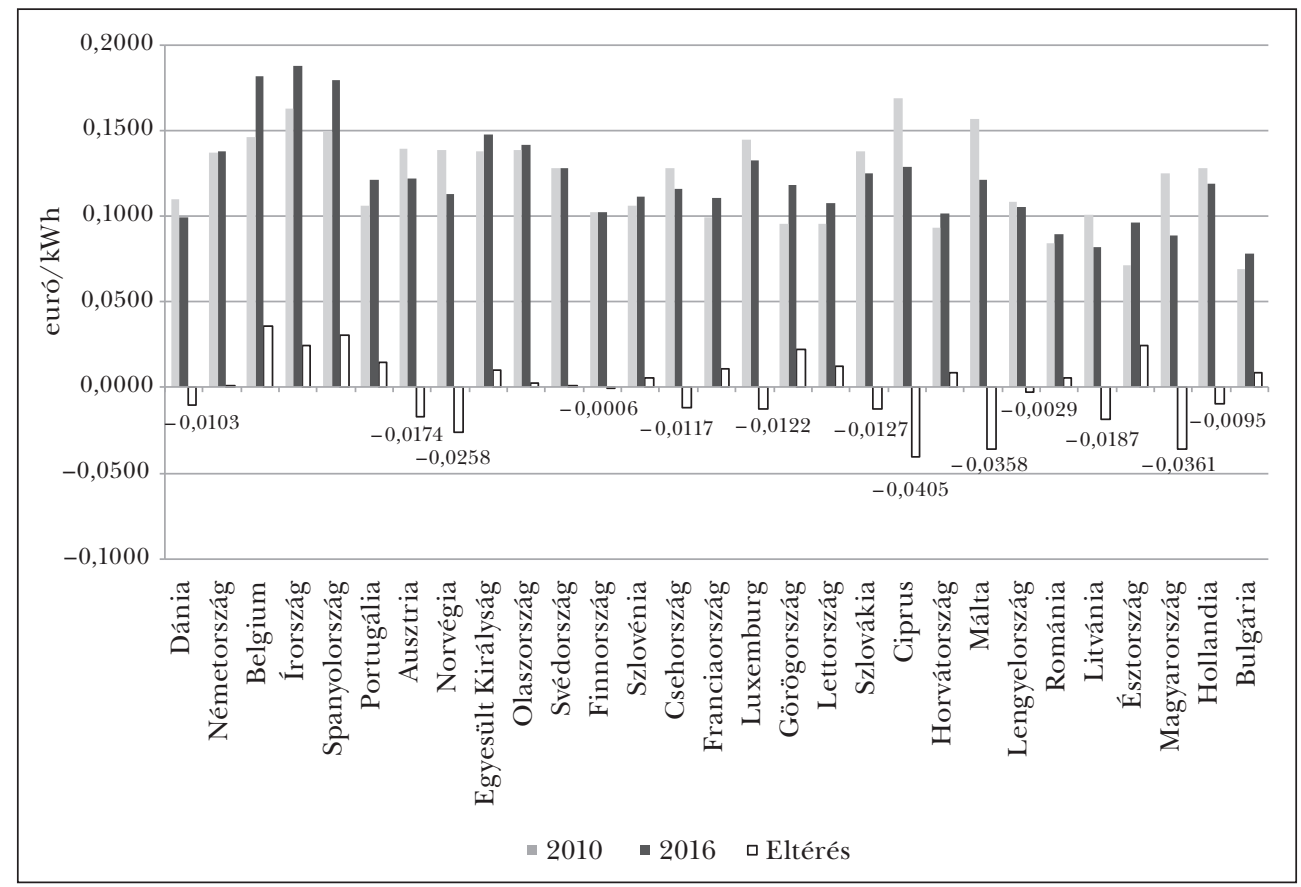

Forrás: Eurostat, 2007b 
A rezsicsökkentés legtöbbször a szolgáltatók extraprofitjának kárára történik, ezért harcolnak a szolgáltatók ellene minden eszközzel, az Európai Unió vezetô politikusait, egyes intézményeinek vezetőit és érdekeiket érvényesíteni kész szakembereket, újságírókat is bevonva, külföldön és belföldön egyaránt. Az Európai Unió bürokratái a közmúszolgáltatók lobbistáinak nyomására totális támadást készítettek elô. Olyan egységes uniós szabályozást kívánnak bevezetni, amely révén mindenféle árszabályozás, árkorlátozás lehetôségét megszüntetnék a tagországok számára. Így a közmúszolgáltatók a profitjuk akár korlátlan emelése érdekében évente többször is emelhetnék a gáz, az áram és más közmúvek árát a fogyasztóik kárára. Ismét oda juthatnánk, ahová a 2010 elôtti kormányok idején: drasztikusan megemelkednének a rezsiköltségeink, rezsiszámláink, kevesebbet tehetnénk félre, költhetnénk életminôségünk javítására, tudásunk megújítására, egészségesebb életmódra, rekreációra, pihenésre, szabad idónk tartalmasabb eltöltésére.

Valószínúleg nem minden EU-tagország képes arra, amire Magyarország, hogy állami szabályozással tegye olcsóbbá az energia árát a háztartások, késôbb az ipar, majd a gazdaság egésze számára. De nyilvánvalóan nem szeretnénk, hogy elvegyék tôlünk azokat az eszközöket, amelyekkel jelentôs eredményeket tudtunk elérni. Ezért Magyarországnak a leghatározottabban ki kell állnia az eddig követett álláspontja mellett, és nem szabad lemondania az energiaárak állami szabályozásának eszközeirôl, ki kell állnia a rezsicsökkentés folyamata mellett. Ha a jövóben Európában valóban létrejön egy olyan egységes energiapiac, amely a fogyasztók számára az árak csökkenését hozza, akkor Magyarország számára is vonzó lehet egy ilyen gazdasági környezetet kialakítani. Addig azonban az Európai Bizottságnak kellene bizonyítania, hogy képes állampolgárai érdekeit megvédeni egy szúk lobbicsoport profitérdekeivel szemben. A jövooben fel kell lépnie az olyan magán-energia- és közszolgáltatók ellen, amelyek visszaélnek erôfölényükkel, és túlszámlázással vagy felesleges, pazarló költségeik áthárítása révén megkárosítják a fogyasztókat.

\section{JEGYZETEK}

1 Például az Egyesült Királyságban, lásd errôl részletesebben Mulgan, 2008 múvében.

2 Lásd részletesebben a 2013. évi LIV. törvényt a rezsicsökkentés végrehajtásáról.

3 Az elemzésben közölt adatok legfeljebb plusz-mínusz 3,2 százalékponttal térhetnek el a mintavételbôl fakadóan attól az eredménytôl, amit az ország felnôtt lakosságának a megkérdezése eredményezett volna (Századvég, 2013).

\section{FELHASZNÁLT IRODALOM}

Baker, Keith (2015): Metagovernance risk and nuclear power in Britain. In: Multi-Level Governance: the Missing Linkages. Szerk. Edoardo Ongaro, Emerald Group Publishing, Bingley, 247-271.

Borrell, Lucinda (2016): SSE freezes energy prices until April 2017 - but you can slash bills by switching. MoneySavingExpert.com, 18 November, www.moneysavingexpert.com/news/energy/2016/11/sse-freezes-prices-until-april-2017 (Letöltés: 2017. június 12.).

CMA (2016): Energy market investigation. Final Report, 24 June 2016, Competition \& Market Authority.

Cole, Martin - Parston, Greg (2006): Unlocking Public Value. A New Model for Achieving High Performance in Public Service Organizations. John Wiley \& Sons, Canada, 188. 


\section{Novoszáth Péter: Karcsúsított kormányzás és rezsicsökkentés}

European Commission (2014): Trends and Developments in European Energy Markets 2014. Commission staff working document, Brussels, 13.10.2014. SWD (2014) 310 final, 33.

Eurostat (2007a): Gas prices for domestic consumers - bi-annual data (from 2007 onwards). [nrg_pc_202].

Eurostat (2007b): Electricity prices for domestic consumers - bi-annual data (from 2007 onwards). [nrg_pc_204].

Felsmann Balázs (2016): Az európai energiaunió és hatásai Magyarországra. „Energiaunió - a jövô” konferencia, Regionális Energiagazdasági Kutatóközpont, Zalaegerszeg, 2016. október 21., http:/ / docplayer. hu/41682319-Az-europai-energiaunio-es-hatasai-magyarorszagra.html (Letöltés: 2017. június 14.).

Feser, Edward J. (2007): Globalization, regional economic policy and research. In: Globalization and Regional Economic Modeling. Eds. Russel Cooper, Kieran Donaghy, Geoffrey Hewings, Springer Verlag, Heidelberg.

Hír TV (2017): „A rezsicsökkentés blöff”, az uniós rendszer müködik. http://hirtv.hu/hirtvkulfold/a-rezsicsokkentes-bloff-az-unios-rendszer-mukodik-1388965 (Letöltés: 2017. június 14.).

Horváth Zoltán (2016): A rezsicsökkentés eredményei. VDSZ konferencia, Nemzeti Fejlesztési Minisztérium, Budapest, 2016. december 1.

Koltai Luca (szerk.) (2014): Éves jelentés a lakhatási szegénységrôl 2013. Habitat for Humanity Magyarország, 6.

Magyar Idôk (2017): Részvételi rekordot hozott a Nemzeti Konzultáció. Magyar Idók, május 31., http:// magyaridok.hu/belfold/reszveteli-rekordot-hozott-a-nemzeti-konzultacio-1771627/ (Letöltés: 2017. június 13.).

Magyar Nemzet (2013): Rezsicsökkentés: magyar mintára segítenek a briteken. Magyar Nemzet, szeptember 26., https://mno.hu/belfold/rezsicsokkentes-magyar-mintara-segitenek-a-briteken-1186533 (Letöltés: 2017. június 9.).

Magyarország Kormánya (2017): Összefoglaló a Nemzeti Konzultáció kérdéseivel kapcsolatban. www.kormany.hu/ download/d/1d/01000/Nemzeti\%20Konzult\%C3\%A1ci\%C3\%B3.pdf (Letöltés: 2017. június 14.).

Miller, Ken (2009): The Promise of Going Lean. Governing, May 21.

Moore, Mark H. (1995): Creating Public Value. Strategic Management in Government. Harvard University Press, Cambridge, MA, 402.

Mulgan, Geof (2008): Public value, reform and innovation. Prime Minister's Strategy Unit.

Novoszáth Péter (2011): A közszolgálati menedzsment legújabb irányzata: a közösségi értékteremtés. Gazdasági Élet és Társadalom, 3. évf., 1-2. sz., 341-357.

OECD (2010): Economic Globalization Indicators 2010. OECD Publishing, Paris.

Pickard, Jim - Thomas, Nathalie (2017): Conservatives promise to cap prices in UK energy market. Financial Times, April 23, www.ft.com/content/d6f949e2-280b-11e7-bc4b-5528796fe35c (Letöltés: 2017. június 9.).

Somogyi Orsolya (2015): Megvédi a kormány a rezsicsökkentést. Magyar Idôk, december 3.

Századvég (2013): A többség a bírálatok ellenére is támogatja a rezsicsökkentést. www.szazadveg.hu/hu/kutatasok/az-alapitvany-kutatasai/elemzesek-publikaciok/a-tobbseg-a-biralatok-ellenere-is-tamogatja-arezsicsokkentest (Letöltés: 2017. június 9.).

Venegas, Carlos (2007): Flow in the Office. Implementing and Sustaining Lean Improvements. Productivity Press, New York.

Waits, Carl (2008): Performance is the best Politics. How to create high-performance government using Lean Six Sigma. HPG Press. 